Article Type: Research Paper

\title{
Liberating Accounting with a Religio-Cultural Approach
}

\author{
Virginia Nur Rahmanti ${ }^{1 *}$ and Tjiptohadi Sawarjuwono ${ }^{2}$
}

\begin{abstract}
:
Research aims: Accounting as a product of Western thought is believed to be loaded with masculinity values such as egoism, rationalism, materialism, and objectivism. The Western perspective of social reality runs counter to the Islamic philosophy of religiosity. Capitalism in pragmatic accounting has led to religiocultural anomalies that have resulted in injustice, domination, and the formation of a class society. This study aims to liberate accounting from masculine characteristics by using Islamic values.

Design/Methodology/Approach:The effort to liberate pragmatic accounting in this study is in line with the thoughts of Ali Ashgar Engineer (1999). He uses Islamic theology as a fundamental in carrying out the liberation. At the methodological stage, this research uses historical studies (historical research) which is extended by phenomenology. Apart from being aimed at identifying Islamic values, historical research is also applied to find out how these values are used to criticize pragmatic accounting. Meanwhile, the phenomenological methodology is used to understand how religious values can create prosperous accounting.
\end{abstract}

THIS ARTICLE IS AVAILABLE IN:

http://journal.umy.ac.id/index.php/ai

DOI: $10.18196 / j a i .2103161$

\section{CITATION:}

Rahmanti, V.N., \& Sawarjuwono, T. (2020). Liberating Accounting with a Religio-Cultural Approach . Journal of Accounting and Investment, 21(3), 492-513.

\section{ARTICLE HISTORY}

Received:

07 July 2020

Reviewed:

8 August 2020

$14 \mathrm{Jul} 2020$

14 Aug 2020

Revised:

13 August 2020

$30 \mathrm{Jul} 2020$

19 Aug 2020

Accepted:

19 Aug 2020

Research Findings: The results showed that monotheism, justice, brotherhood, benefit, balance, gratitude, sincerity, and blessings are Islamic values that are often used by researchers to criticize pragmatic accounting. Analysis of a collection of empirical articles also proves that pragmatic accounting is indeed full of masculinity. By using business as an accounting metaphor, internalization of Islamic values is proven to be able to create a prosperous business. Thus, the internalization of Islamic values will be able to liberate accounting from masculinity.

Theoretical Contributions/Originality: This research is expected to provide insight into accounting studies using a different approach to previous research, namely by using the basis of Islamic theology.

Keywords: Accounting; Masculinity; Religious; Theology; Islam; Liberation.

\section{Introduction}

Accounting is justified by critical researchers as a science contributing to the flourishment of capitalism. Chiapello (2007) sees that accounting tent to be deifying financial market and prioritizing shareholder's' interest as the materialization of neoliberalism-loaded financialization. In addition, Farjaudon (2013) perceives that accounting standard setting process has also been penetrated by the fundamentals of capitalism that triggers inter-classes hegemony. According to Carrier (2005: 443), accounting as a science has been criticized since the 20th century is that it refers to economic redefinition as a study that focuses on price shaping, which 


\section{Rahmanti \& Sawarjuno \\ Liberating Accounting with a Religio-Cultural Approach}

ends in rejection of intrinsic value whatsoever, such as religions and ethics, so there is no other form of justice but the market itself (Mulawarman \& Kamayanti, 2018).

The internalizations of capitalistic value in accounting is evident in its theoretical framework consisting of its objectives, qualitative characteristics, assumptions, principles, and limitations (Kieso, Jerry, \& Terry, 2011:17). It is clearly stated that the objective of financial reporting is providing information about the activities of entities beneficial for investors, and creditors. This confirms that accounting prioritizes capital holder's wellbeing (Bryer, 2000; Catchpowle et al., 2004; Chiapello, 2007) over the stakeholders' wellbeing. Accounting's market orientation is the impact of rationality superiorization, which leads to materialistic psyche. Affirmed by Burrell and Morgan (1979:25) that positivism, widely accepted by accountants, is an accounting perspective brimful of rationalism in discerning social reality.

The most phenomenal "pragmatic accounting" model of recording referring to conventional accounting - is double-entry bookkeeping. Funnell and Robertson (2011), in mention of Yamey (1949), confirmed that the said bookkeeping contributes to the development of capitalism. It is ostensive in the use of ledgers closely related to profitloss account. This system is certainly based on secularism. Sawarjuwono (2002) in Accounting is Magic? shows how accounting recording supports capitalism. The word "magic" appertains to the ability of accounting to convince information users concerning the trust of economic reality it created. The relative truth in the reality is engineered through the flexibility of accounting treatments in the absence of negative manipulation, so it very close with both institutional and individual interests.

Secularism is the nucleus of masculinity inherent in pragmatic accounting. Its traits, i.e. egoism, rationality, materialism, and objectivity, opposes the altruism, intuitiveness, spiritualism, and subjectivity of Islam. The antithesis of the values is caused by hierarchical distinction between Islam and the West in value creation. Ahmad (2020) stated that, as West creates value from social interactions, Islam relies on God-guided thoughts, the real source of truths. Hence, Ahmad (2020) confirmed that Islamic values are the most applicable reference for human behavior.

This study attempts to liberate pragmatic accounting from its masculinity using Islamic values. Different from other religions, Islam provides a comprehensive guidance for human in their material and spiritual lives (Ahmed \& Barikzai, 2016). Islamic monotheism, the tawhid, the recognition that God is the core of human life, is able to create social order (Choudhury, 1989). In other words, values brought by Islam certainly brings virtues for human. Its teaching, in addition to becoming the distinguishing point from other religions, has been attested of shaping a more altruistic human way of thinking. Asserted by Sarker (1999), Haniffa and Hudaib (2007), and Asutay (2008), happiness according to capitalism lies in the achievement of wealth maximization, but Islam teaches that falah is the goal of life, i.e. success in life and the hereafter. Therefore, integrality in Islam bring positive implications for social welfare. This is the rationale of this research for using Islamic values in liberating pragmatic accounting. 


\section{Rahmanti \& Sawarjuno \\ Liberating Accounting with a Religio-Cultural Approach}

"Value" is both purpose and perspective. In the context of Islamic teaching, tawhid, 'adl, amanah, and ubudiyah are core values underlying human activities (Ahmad, 2020). The should also be used as the understructure of all scientific development; as by Choudhury (1989), who uses Islamic values as the center of all science. Tawhid as the core of Islamic theology does not only teach the unity of God but also the unity of mankind (Engineer, 1999:11). Tawhid as a concept always use the Quran to create justice and virtue (al-'adl wa al'ahsan). The Islamic concept of justice called as 'adl in the Quran means equal distribution including the distribution of wealth (Engineer 1999:60). This contradicts capitalistic view, which is oriented more on elite groups, similar to pragmatic accounting, which prioritize the welfare of capital holder (shareholders and creditors).

By referring to the paradox between Western and Islamic values, we believe that the latter can liberate accounting from masculinity. There are many researchers who have attempted to combine accounting and spiritual aspect; they are Nurindrasari, Triyuwono, and Mulawarman (2018), Fauzia (2018), Soediro and Meutia (2018), Urumsah, Wicaksono, and Hardinto (2018), Jurana and Khairin (2017), Kusdewanti and Hatimah (2016), Kamayanti (2016), Farhan (2016), Muchlis and Sukirman (2016), or Indriasari (2015), who used Islamic values as the antithesis for capitalism. However, the studies used Islamic values in a partial way in criticizing pragmatic accounting. Therefore, this research tries to use a more comprehensive Islamic values in liberating accounting through historical studies on several researches. Furthermore, in criticizing the masculine value of accounting, past studies only used Islamic values without proving that Islamic value internalization really creates a better social condition. Using transcendental phenomenology, this research addresses the shortcoming by trying to answer the questions of (1) what religious values frequently used in critical studies on accounting, (2) how the religious values are used to criticize pragmatic accounting's masculinity, and (3) how religious values can liberate pragmatic accounting from its masculinity. To answer the first two problems, we apply historical study in analyzing a number of empirical articles, and the third problem is answered by applying transcendental phenomenology through in-depth interviews with selected informants. There are not many researches that criticize pragmatic accounting using the awareness of the subject in an activity and use business activity - as employed in this research to prove that Islamic value internalization is able to liberate pragmatic accounting from masculinity - as the metaphor of accounting.

This research is divided into six chapters. As the first chapter will set out critical studies on pragmatic accounting's masculinity, the second will elucidate Islamic fundamental values as the antithesis of masculinity. Methods incorporated to complete this research will be presented in the third chapter. The results and the analysis will be presented separately in the fourth chapter so that information about the process of liberating pragmatic accounting is better delivered. Finally, this research will be concluded in the last chapter. 


\section{Rahmanti \& Sawarjuno \\ Liberating Accounting with a Religio-Cultural Approach}

\section{Literature Review}

\section{The Masculinity of Pragmatic Accounting}

Masculinity is frequently analogized as the power to colonize human (Davie, 2010), evidenced by the penetration of accounting to Indian workers in 19th to 20th century. In the context of accounting, gender and role differences are frequently used to voice criticism (Haynes, 2017). The biological gender between male (masculine) and female (feminine) are implemented in critical studies on accounting, as in Gallhofer (1998); Hammond (2003); Haynes (2017); and Nichols, Robinson, Reithel, and Franklin (1997).

How masculinity is attached in accounting can be explained by understanding the role of a culture in shaping its members' mindset. It is justified that accounting science is the product of Western culture. Eliot (1948), as quoted by Kohzadi and Azizmohammadi (2011), stated that culture is a way of life. According to Plog and Bates (1976), culture is any faith, habit, behavior, or artifact used by community members to live in their realm and live with others transmitted from generation to generation through learning processes. In anthropology it is believed that civilization is shaped from assumptions about the core of culture (Mulawarman \& Kamayanti, 2018). Anthropology is defined as a study on human's historical evolution (Hasegawa, 2010), not limited to physical evolution but encompassing the combination between humanity and social science. The relation between masculinity and Western culture is explained by Capra (2000: 144) as follows.

\footnotetext{
"Westerners traditionally put masculinity over femininity... Western tradition even established a static order... causing overemphasis on the "Yang" or the masculinity of human nature: active, rational, competitive, aggressive... The "Yin" - or female - mode of awareness that can be described as intuitive, religious, mystical, devotion, and spiritual..."
}

The quote implies that masculinity is closely related to rationality endorsement. Burrel and Morgan (1979) stated that at epistemological level positivists tend to look for order and causal relationship between elements in contemplating what happens with the social world. Hence, complex social realities are reduced by them as causal relationship that can be rationalized. Such endorsement has given birth to materialism that has always been oriented to material gains. Thus, the masculinity of accounting is the product of a culture.

Meanwhile, there is a strong relationship between culture and power. How the two are related can be explained through a phenomenon about the belief or tendency of scientists concerning Western's political and economic systems that produce what we call as westernization. The capitalism-loaded Western culture (Abdurahim, 2013; Chiapello, 2007) with its superiority assumption has reached all areas, including accounting. The agent of capitalism proliferation, i.e. the umbrella of masculinity, uses corporatocracy as well as education. Accounting has become an example of how it serves as the agent that replaces Eastern culture with Western. Due to accounting. The 


\section{Rahmanti \& Sawarjuno \\ Liberating Accounting with a Religio-Cultural Approach}

previously collective, helpful and cooperative, tolerant, and cordial Eastern people have become individualistic and materialistic. This cultural shift occurs for there is an assumption that Western culture is the center of knowledge, which is the impact of rationale superiority.

Accounting is misunderstood as a "value-free" recording tool. This statement becomes incorrect when we refer back to studies on culture and masculinity above. That statement will become even more mistaken if we believe that accounting is the agent capitalistic value dispersion. The world's faith on the absolute truth of pragmatic accounting is the indication on the successful Western' hegemony. Even Muslims, who believe that God is the source of truth, are trapped by the accounting-manufactured truth. Sawarjuwono (2002) asserted that this false truth is crammed with interests that is very likely to produce injustice.

The theoretical framework of accounting, particularly in the purpose financial reporting, clearly signifies the masculinity of accounting through capital holder's interest prioritization. In spite of its definitive context mentions that financial reporting is purported to help stakeholders in their decision making, accounting breaks the definition by putting stockholders and lenders' interest on the top priority. This confirms Sawarjuwono (2002) that accounting is not interest-free. The market-oriented pragmatic accounting (Mulawarman \& Kamayanti, 2018) tend to prioritize the interest of capital holders by presenting quality financial report. Therefore, it is not surprising if pragmatic accountants always try to maximize corporate profit or assets.

Elite-oriented westernization conceivably causes religio-cultural alienation (Engineer 1999: 24, 60). Justice, one of the teachings of Islam, is called as 'adl and qist, an equitable distribution, including wealth distribution. In economic context, one of the Western concepts that opposes to justice value is the use of interest. Allah forbids usury, as stated in the Quran surah number 3 verse 130, surah number 4 verse 161, and surah number 2 verse 275 to 278 . Pragmatic accounting is closely affiliated with usury practices as reflected in the use of "interest cost" account in profit-loss report. There are many accounting products that apply interest as the consequence of debt; say the accounting treatment for bonds and money orders. This is not a problem for positivists because they believe "the truth of accounting", a truth coming from rationality but not the real truth coming from Allah SWT. By referring to pragmatic accounting's spiritualistic value negligence, it can be concluded that secularism is the antecedent of masculinity.

We believe that Islamic values are able to liberate accounting from the enmeshment of masculine traits. It is not an easy thing to break the status quo of pragmatic accounting, whose truth is universally recognized. Nevertheless, this attempt is very meaningful considering that accounting is believed to be loaded with values. If pragmatic accounting practices are ignored, it is not impossible that it pushes Easter culture farther away. Culture is closely related to value, as expressed by Bozeman (1975) that: 


\author{
Rahmanti \& Sawarjuno \\ Liberating Accounting with a Religio-Cultural Approach
}

"civilization and culture both refer to the overall way of life of a people that involve values, norms, institutions, and modes of thinking to which successive generations, in a given society, have attached primary importance".

The decimation of Eastern culture by Western culture also refers to the changes from religious and collective to secularistic and individualistic. Finally, this phenomenon will cause social disaster such as injustice, oppression, and the birth of segregated society.

\title{
2. The "Strength" of Islamic Values as the Antithesis of Masculinity Values
}

In contrast to masculinity, (Tong, 1991) has introduced (Western) feminism as a form of struggle against male oppression. Feminism as the opposite of masculinity is actually not a truth. Kamayanti (2013) asserted that feminism is also a term native to Western thinking, so it is still full of capitalistic values. If capitalistic values were created from local customs and traditions, Islamic values came from God as the only source of truth (Ahmad, 2020). She then explained the different thought evolutions between the West and the East (see figure 1). The evolutions contrast each other. Western thoughts believe that values are shaped by traditions and localities, which then developed into social habit and behavior, where people's behaviors refer to something perceived as the truth. When those perceived to be true materialize into people's behavior, at that time values are created. Thus, western's thought evolution is inductive. On the contrary, values of Eastern culture were derived from the believe that all things come from the words of God and that those coming from God's words are the real truths. Ahmad (2020) refers to it as the "divine guidance", which grows into universally accepted values that guide human behavior.

Continuing his explanation about value, Ahmad (2020) mentioned that there are four core values of Islam that serve as the foundation of human activity; they are tawhid, 'adl, amanah, and ubudiyah. Even though he did not explain tawhid in detail, we can predict why tawhid is considered as one of the core values. Tawhid is an attestation that Allah is the only one deserving human's reverence because Allah is the true source of truth. As the core of Islamic theology, it is interpreted as God's unity and unity of mankind (Engineer, 1999). This statement implies that the evidence of tawhid is not only praying routines but also human civilization that complies with Islamic values.

In relevance with Ahmad (2020), Engineer (1999:11) asserted that the concept of tawhid is very close to justice and virtue (al 'adl wa al' ahsan). The Quran teaches humankind to be fair and bring virtue at all times. This command is stated in the Quran surah number 16 verse 90, "Allah orders justice and good conduct", and surah number 5 verse 8 , "Be just; that is nearer to righteousness". The surahs above highlight the link between justice and taqwa (righteousness and piety). Taqwa is the concept of human piety to Allah SWT by doing His commands and avoiding what He forbids. The surahs implies that taqwa cannot be simply defined as rituals; it also means doing God's command, including upholding justice. A person cannot be said understanding Islamic teaching and its essence if he still put the concept of socio-economic justice aside (Engineer, 1999:39). 


\author{
Rahmanti \& Sawarjuno \\ Liberating Accounting with a Religio-Cultural Approach
}

In order to uphold justice, Islam requires that wealth must not be controlled by elites. Allah even condemns and will punish those who accumulates wealth (the Quran surah number 9 verse 34 and 35, surah number 17 verse 16 . This concept, according to (Rahmanti, Kamayanti, \& Mulawarman, 2013), is called flow concept.

Contrasting the flow concept, the capitalism-oriented Western thinking is brimful of stock concept, the accumulation of wealth on certain groups. The ordination of wealth is potential to create oppression, as accounting that promotes stockholders' interest over the stakeholders' through profit and asset maximization. The greed of accounting over wealth is the reflection of its masculinity. Kamayanti (2013) characterizes masculinity as aggressiveness and rationality, while Heidhues and Patel (2012) relate masculinity with the inclination to material success. All of the masculine traits are embedded in the "body" of pragmatic accounting. Hence, we can conclude that masculine values are the primogenitor of injustice, which opposes Islamic values.

As Ahmad (2020) understood that tawhid, 'adl, amanah, and ubudiyah as the core values of Islam, Dusuki (2008) delivered the idea of Hassan (2002) that Islamic values include honesty, perseverance, justice, honor to law, virtues, patience, tolerance, and truth. According to Kamla (2009); Maali and Napier (2010), Islamic values cover accountability, equality, justice, morality, responsibility, and social justice. Therefore, Islam has many virtuous values as the guideline for Muslims in their behavior.

\title{
Research Method
}

The purpose of this study is to liberate pragmatic accounting from masculinity suing Islamic values. The attempt is done through two methodological phases. to answer the first two questions, i.e. (1) what religious values frequently used in critical studies on accounting and (2) how the religious values are used to criticize pragmatic accounting's masculinity, we apply historical study in analyzing a number of empirical articles. Špiláčková (2012) revealed that "The main task of historical research is to gather all available information and sources as to a particular topic, and subsequently to classify, arrange, clarify, evaluate, elaborate and publish them by means of scientific methods. The articles were compiled from Jurnal Akuntansi Multiparadigma (JAMAL), a journal specific to themes of locality, spirituality, and culture, in the publishing period of 20152019. The journal is also rich of research articles with various perspective and methodology, which adds the researchers' knowledge in how pragmatic accounting should be criticized.

To answer the third problem, i.e. how religious values can liberate pragmatic accounting from its masculinity, we conducted exploration using phenomenology to reveal informants" awareness. There are three informants involved in this study; they are female Muslims engaged in service, manufacture, and trade business. They were selected upon meeting two main requirements: Muslim and having been running the business at least one year. The first requirement is expected to provide the researchers with information about Islamic values applied by the informants in running their 


\section{Rahmanti \& Sawarjuno \\ Liberating Accounting with a Religio-Cultural Approach}

business. This process also serves as a confirmation (triangulation method) of the value exploration stage used in the first method, i.e. historical study), so the data validity improves. The second requirement was used to ascertain that the Islamic values believed by the informants have been applied in their business activities. We used business as the metaphor of accounting since both have similarities in certain aspects.

The three informants understand the cycle of their business. They were selected not only due to their agreement to share information but also due to the researcher's consideration after observing their track record from starting the business until this research was conducted. The researchers even have records on the business' epiphanies. To keep the informants' anonymity, the researchers use their initials in referring to them. They, $R, S$, and $D$, have agreed the use of voice recorders and even allowed the researchers to observe the running of their business. This convenience has allowed the researchers to use phenomenology.

Transcendental phenomenology focusing on awareness was applied in this phase. Kamayanti (2017:153) mentioned that the stages of transcendental phenomenology analysis technique are noema, noesis, epoch, intentional analysis, and eidetic reduction. Noema is a phenomenological term referring to visible awareness. Epoch, or bracketing, refers to concentration on certain findings for further analysis to identify how such findings happen. Different form noema, noesis refers to awareness due to experiences at certain times (allraum) and certain places (welzeit). Intentional analysis sees how noesis shapes noema. In other words, it leads to a reason behind the occurrence of actions or behaviors. Eidetic reduction, the final stage, reveals the condensation of the entire process of interpretation.

Following the collection, the data was then analyzed in several stages. First, the researchers identified the Islamic values through historical study on recent articles. Second, how the values are used to criticize pragmatic accounting were understood and analyzed to support the research premises that Islamic values as the antithesis of masculinity can lead to a better social condition. This phase was concluded by liberating pragmatic accounting from masculinity using Islamic values. This is relevant with Engineer (1999), referred to as theological framework-based liberation. Thus, the implementation of phenomenology in this research also functions as triangulation for research data validity improvements.

\section{Result and Discussion}

\section{Result}

In the highlight of the research stages above, we mapped the historical study-based articles to identify Islamic values frequently used in critical studies on accounting. We took a number of articles during the publishing period of 2015-2019. The detail of the map is available in Table 1 . In order to be selected, the articles must fulfill the main requirement of relating accounting with Islamic spirituality. 


\section{Rahmanti \& Sawarjuno}

Liberating Accounting with a Religio-Cultural Approach

Table 1 The Map of Current Studies

\begin{tabular}{|c|c|c|c|c|c|c|}
\hline No & $\begin{array}{l}\text { Volume/ } \\
\text { Number }\end{array}$ & Title & Keywords & Value Coding & Author & $\begin{array}{l}\text { Islamic } \\
\text { Value }\end{array}$ \\
\hline 1 & Vol. 9 No. 3 & $\begin{array}{l}\text { Islamic Welfare-Based Performance } \\
\text { Measurement Concept }\end{array}$ & $\begin{array}{l}\text { Interpreting the concept of economic activities as forms } \\
\text { of reverence to God, peacefulness, material fulfilment } \\
\text { for others and the universe }\end{array}$ & $\begin{array}{l}\text { Ibadah (worship or reverence to } \\
\text { God), peacefulness, material } \\
\text { distribution justice }\end{array}$ & $\begin{array}{l}\text { Nurindrasari et al. } \\
\text { (2018) }\end{array}$ & \multirow{10}{*}{$\begin{array}{l}\text { Tawhid, } \\
\text { justice, } \\
\text { brotherhood, } \\
\text { maslahah } \\
\text { (public } \\
\text { interest), } \\
\text { balance, } \\
\text { gratefulness, } \\
\text { sincerity, } \\
\text { blessing }\end{array}$} \\
\hline 2 & Vol. 9 No. 1 & $\begin{array}{l}\text { The Behavior of Business people and } \\
\text { Entrepreneurs in Applying Islamic } \\
\text { Transaction Principles }\end{array}$ & $\begin{array}{l}\text { Perspective difference between informants concerning } \\
\text { brotherhood, justice, maslahah, and balance }\end{array}$ & $\begin{array}{l}\text { Brotherhood, justice, maslahah, } \\
\text { and balance }\end{array}$ & Fauzia, (2018) & \\
\hline 3 & Vol. 9 No. 1 & $\begin{array}{l}\text { Maqasid Sharia as a Performance } \\
\text { Framework for Islamic Financial } \\
\text { Institutions }\end{array}$ & Maslahah, Rahmatan lil 'alamin, and khalifatu fil ardh & Maslahah, tawhid & $\begin{array}{l}\text { (Soediro \& Meutia, } \\
\text { 2018) }\end{array}$ & \\
\hline 4 & Vol. 9 No. 1 & $\begin{array}{l}\text { Are Religiosity and Organizational Culture } \\
\text { Significant in Reducing Frauds? }\end{array}$ & Religious values can prevent frauds & Tawhid & $\begin{array}{l}\text { (Urumsah, } \\
\text { Wicaksono, \& } \\
\text { Hardinto, 2018) }\end{array}$ & \\
\hline 5 & Vol. 8 No. 1 & $\begin{array}{l}\text { Liberation of Educator Accountants' } \\
\text { Mindset through Science Philosophy and } \\
\text { Spiritual Learning }\end{array}$ & $\begin{array}{l}\text { God as the single truth, spiritual values are the core of } \\
\text { science, urgency of accounting purgation }\end{array}$ & Tawhid & $\begin{array}{l}\text { (Jurana \& Khairin, } \\
\text { 2017) }\end{array}$ & \\
\hline 6 & Vol. 7 No. 2 & Building Prophetic Accountabilities & $\begin{array}{l}\text { Prophetic accountabilities contain the element of } \\
\text { ibadah, life that enlightens, amar ma'ruf nahi munkar, } \\
\text { sacral genesis of divinity }\end{array}$ & Ibadah & $\begin{array}{l}\text { (Kusdewanti \& } \\
\text { Hatimah, 2016) }\end{array}$ & \\
\hline 7 & Vol. 7 No. 1 & $\begin{array}{l}\text { Phobi(A)ccounting: } \\
\text { Poeticization and Reflection of Haqiqa }\end{array}$ & Accounting is inseparable from tawhid concept & Tawhid & (Kamayanti, 2016) & \\
\hline 8 & Vol. 7 No. 1 & $\begin{array}{l}\text { Schleiermacher's Romantic Hermeneutics } \\
\text { Concerning Profit in the Muqaddimah of } \\
\text { Ibnu Khaldun }\end{array}$ & $\begin{array}{l}\text { Earnings are incidentally gained profits, which are the } \\
\text { compassion of Allah SWT. }\end{array}$ & Grateful & (Farhan, 2016) & \\
\hline 9 & Vol. 7 No. 1 & $\begin{array}{l}\text { The Implementation of Maqasid al-Sharia } \\
\text { in Corporate Social Responsibility at PT } \\
\text { Bank Muammalat Indonesia }\end{array}$ & $\begin{array}{l}\text { The concept of guarding assets emphasizes } \\
\text { stakeholders' and customers' welfare }\end{array}$ & Stakeholder's' welfare & $\begin{array}{l}\text { (Muchlis \& } \\
\text { Sukirman, 2016) }\end{array}$ & \\
\hline 10 & Vol. 6 No. 2 & $\begin{array}{l}\text { When [Accounting] Science Glorifies the } \\
\text { Spirit of Love }\end{array}$ & $\begin{array}{l}\text { Accounting can recover its beauty and sincerity with the } \\
\text { energy of love, so its actors [accountants] can harvest } \\
\text { love and blessing }\end{array}$ & Sincerity, blessing & (Indriasari, 2015) & \\
\hline
\end{tabular}


To improve data validity, we also conducted an empirical research through in-depth interviews. The informants' identity is detailed in Table 2.

Table 2 Informant's Identity

\begin{tabular}{cclc}
\hline No. & Name (initial) & \multicolumn{1}{c}{ Business Fields } & Business Age \\
\hline 1. & R & Service (Daycare) & 4 years \\
2. & S & $\begin{array}{l}\text { Manufacture (Japanese Food } \\
\text { Restaurant) }\end{array}$ & 14 years \\
3. & D & Trade & 10 years \\
\hline
\end{tabular}

The first informant is $\mathrm{R}$, a young mother who has been running a daycare business since 2016. Based on the increasing number of customers, her business develops quite well. She employs five people who work as child attendants. We give unstructured questions to her during the interview to reveal how Islamic values "guide" her running the business. The following is the transcription of her responses.

"I do business for \{material and life blessings\}. To me, much money is \{useless in the absence of God's blessing\}. I want to help mothers who cannot look after their children because they have another duty (working) to do. We do not know their (mothers') reason of not being able to leave their job. In fact, one of the mothers is a single parent; she has to work."

"Thank God, I have five employees who help me. They are like \{my family to me\}. Some of them are married, but some of them are not. \{l feel happy\} when they can provide for their family from what they get from this business, so I do my best to make them feel comfortable and stay. About their salary, I never feel that I have to pay them with the same amount of money every month. If we get more income, I give them bonuses in forms of either money or voucher. My point is that for me happiness is when I see my employees happy, ffeeling comfortable working here and staying\}. If I am being authoritarian, I can get maximum income, but \{it is not\} my orientation."

We visited $\mathrm{R}$ many times to find the best time and moment to talk. Every interview session took a long time until we finally found how Islamic values that she believes can help her running her business.

After the interviews with the first informant was concluded, we continued to visit $S$ to collect data. She has been running a Japanese fast food business for fourteen years. Using the same questions, we received the following responses.

"Saboten (her restaurant) had branches outside Java, managed using (conventional) franchise system. During the fourteen years of operation, we have been experiencing \{downs and lows (in profit)\} due to, I think, inappropriate system. After some analyses, I found out that there was something wrong with the system; our system was \{not franchisor-friendly\}. 


\author{
Rahmanti \& Sawarjuno \\ Liberating Accounting with a Religio-Cultural Approach
}

I also found that the trend of our turnover indicates low performance. Then I started to learn about \{Islamic business model\} and was interested to apply it. Now Saboten's franchise system uses \{syirkah with profit sharing\}. Thank God, now we are improving a lot. Most of the employees are females. Although some of them had to resign due to marriage or children, most of them stay."

Saboten is a restaurant business that transformed form conventional business to shariacompliant one. The owner also has changed into a more religious person. $\mathrm{S}$ admitted that, after learning about it, she believed that the Islamic system is better than the conventional. Aside from providing peacefulness, the new system is also successful in increasing the performance of all branches.

The last informant is $D$, the owner of a large-scale trade business. Her products are even sold abroad. As with other informants, the researchers have a close friendship with $D$, so it was easy to explore spiritualistic values behind her awareness. The following is the excerpt of the interview with her.

I started my business not only to prosper myself and my family but also \{to help others\}. Honesty and responsibility are my codes. I am a native Malang citizen (Javanese) who always admires Javanese philosophy. One of the principles that I always apply is "do not look up too high and do not look down too low. More or less the meaning is that we must not push ourselves too hard to achieve big things and that we must be grateful when the \{business is low $\}$.

"About income, I talk much with my employees. Their income and comfort matter the most to me. During this pandemic (Covid-19), businesses are collapsing, but we think hard \{about how\} to survive so I do not need to lay them off. In fact, that they make charities is something that gives me goosebumps. They saved some portions of their salary for the charity. They saved some portions of their salary for charity; they said that their salary is more than enough.

After interviewing all informants, we analyzed and related the data with the third research problem, which is how the internalization of Islamic values upheld by the informants helped them in their businesses that are not oriented only on materialism. Following the phenomenological analysis technique, which includes noema, noesis, intentional analysis, and eidetic reduction, the results of the analysis are presented in the following Table 3. 
Rahmanti \& Sawarjuno

Liberating Accounting with a Religio-Cultural Approach

Table 3 The Sequence of Phenomenological Analysis Technique

\begin{tabular}{|c|c|c|c|c|c|}
\hline No. & Noema & Epoch & Noesis & $\begin{array}{l}\text { Intentional } \\
\text { Analysis }\end{array}$ & $\begin{array}{l}\text { Eidetic } \\
\text { Reduction }\end{array}$ \\
\hline \multirow[t]{2}{*}{1} & $\begin{array}{l}\text { I do business for } \\
\text { \{material and life } \\
\text { blessings\} }\end{array}$ & $\begin{array}{l}\text { To me, much } \\
\text { money is \{useless } \\
\text { in the absence of } \\
\text { God's blessing\}; ... } \\
\text { but \{it is not\} my } \\
\text { orientation }\end{array}$ & $\begin{array}{l}\text { If I am being } \\
\text { authoritarian, I } \\
\text { can get maximum } \\
\text { income }\end{array}$ & $\begin{array}{l}\text { R runs her } \\
\text { business not only } \\
\text { to maximize } \\
\text { material gains but } \\
\text { also to find } \\
\text { blessings by } \\
\text { helping others }\end{array}$ & $\begin{array}{l}\text { Business dies } \\
\text { not necessarily } \\
\text { be related } \\
\text { with wealth; } \\
\text { Blessings are } \\
\text { the main key } \\
\text { in business }\end{array}$ \\
\hline & $\begin{array}{l}\text { They are like }\{m y \\
\text { family to me\} }\end{array}$ & $\begin{array}{l}\text { \{I feel happy\} } \\
\text { when they can } \\
\text { provide for their } \\
\text { family from what } \\
\text { they get from this } \\
\text { business }\end{array}$ & $\begin{array}{l}\text { For me happiness } \\
\text { is when I see my } \\
\text { employees happy, } \\
\text { \{feeling } \\
\text { comfortable } \\
\text { working here and } \\
\text { staying\} }\end{array}$ & $\begin{array}{l}\text { Doing business } \\
\text { also means } \\
\text { providing for } \\
\text { many people, so } \\
\text { it is through } \\
\text { business people } \\
\text { can get life } \\
\text { blessings }\end{array}$ & $\begin{array}{l}\text { Blessed life } \\
\text { means useful } \\
\text { for others }\end{array}$ \\
\hline \multirow[t]{2}{*}{2} & \multirow{2}{*}{$\begin{array}{l}\text { During the } \\
\text { fourteen years of } \\
\text { operation, we } \\
\text { have been } \\
\text { experiencing } \\
\text { \{downs and lows } \\
\text { (in profit)\} due to, } \\
\text { I think, } \\
\text { inappropriate } \\
\text { system. }\end{array}$} & \multirow[t]{2}{*}{$\begin{array}{l}\text { Now Saboten's } \\
\text { franchise system } \\
\text { uses }\{\text { syirkah with } \\
\text { profit sharing\}. }\end{array}$} & $\begin{array}{l}\text { Since then I was } \\
\text { interested to } \\
\text { learn about } \\
\text { \{Islamic business } \\
\text { model\} }\end{array}$ & \multirow[t]{2}{*}{$\begin{array}{l}\text { Running business } \\
\text { using Islamic } \\
\text { concept is more } \\
\text { profitable and } \\
\text { reassuring }\end{array}$} & \multirow{2}{*}{$\begin{array}{l}\text { Islamic } \\
\text { concept is the } \\
\text { best; Profit } \\
\text { sharing is } \\
\text { perceived to } \\
\text { be fairer; } \\
\text { when we } \\
\text { orient our life } \\
\text { to the } \\
\text { hereafter, } \\
\text { material } \\
\text { welfare } \\
\text { follows }\end{array}$} \\
\hline & & & $\begin{array}{l}\text { After some } \\
\text { analyses, I found } \\
\text { out that there } \\
\text { was something } \\
\text { wrong with the } \\
\text { system; our } \\
\text { system was \{not } \\
\text { franchisor- } \\
\text { friendly\} }\end{array}$ & & \\
\hline \multirow[t]{2}{*}{3} & \multirow[t]{2}{*}{$\begin{array}{l}\text { I started my } \\
\text { business not only } \\
\text { to prosper myself } \\
\text { and my family but } \\
\text { also \{to help } \\
\text { others\} }\end{array}$} & $\begin{array}{l}\text { Businesses are } \\
\text { collapsing, but we } \\
\text { think hard \{about } \\
\text { how\} to survive so } \\
\text { I do not need to } \\
\text { lay them off }\end{array}$ & $\begin{array}{l}\text { We must not push } \\
\text { ourselves too } \\
\text { hard to achieve } \\
\text { big things and } \\
\text { that we must be } \\
\text { grateful when the } \\
\text { \{business is low\} }\end{array}$ & \multirow[t]{2}{*}{$\begin{array}{l}\text { D's main goal in } \\
\text { doing her } \\
\text { business is to } \\
\text { improve the } \\
\text { welfare of others }\end{array}$} & \multirow[t]{2}{*}{$\begin{array}{l}\text { Life must be } \\
\text { beneficial for } \\
\text { other; } \\
\text { Employees are } \\
\text { the main } \\
\text { stakeholders }\end{array}$} \\
\hline & & $\begin{array}{l}\text { In fact, that they } \\
\text { make charities is } \\
\text { something that } \\
\text { gives me } \\
\text { goosebumps. } \\
\text { They saved some } \\
\text { portions of their } \\
\text { salary for the } \\
\text { charity }\end{array}$ & $\begin{array}{l}\text { Their income and } \\
\text { comfort matter } \\
\text { the most to me. }\end{array}$ & & \\
\hline
\end{tabular}

\section{Discussion}

In this stage, we conducted analyses on two research sources, i.e. empirical articles and interview results. The analysis on the former was conducted to identify spiritual values and to understand how the values are used to criticize pragmatic accounting's masculinity. The analysis on the later was conducted to show how the values can help 


\section{Rahmanti \& Sawarjuno \\ Liberating Accounting with a Religio-Cultural Approach}

the informants with their business. We expected that the analyses can prove that Islamic values as the antithesis of masculinity can liberate pragmatic accounting from its masculinity.

\section{How can Islamic values alter masculinity?}

Referring to the selected articles mentioned in Table 1, we identify Islamic values found in them. After the process completed, the analysis was continued to discussion on how Islamic values are used to criticize pragmatic accounting.

We started the analysis on the first article. It criticizes the concept of balanced scorecard measurement usually applied in the management accounting study. The author believes that this concept opposes human essence as the welfare disseminators, so the most appropriate measurement concept (as a part of economic activity) is by perceiving that the concept is a form of reverence to God that is materialized into distributive justice. Thus, the successfully mapped values are tawhid and justice. Using the second article, we attempted to understand perception about Islamic principles from different informants. In line with this research, the article uses business as accounting metaphor. The study on the article provided us with information that brotherhood, justice, maslahah, and balance are values closely related with business. Therefore, the values will be closely related with studies in accounting science domain. The third article criticizes the basic framework of sharia that should refer to maqasid sharia, i.e. sharia values or objectives. The author thought that the stagnation of Islamic financial institutions' growth in Indonesia is caused by theoretical framework uniformity between conventional and Islamic financial sector. Hence, maqasid sharia, which is full of maslahah and tawhid values, is believed to be the most appropriate concept. Maslahah is sensed as anything related to virtues.

The analysis on the fourth article was conducted to show that Islamic values can reduce frauds, such as those in financial report manipulation. Referring to the author's way of thinking, fraud triangle, consisting of incentive, opportunity, and rationalization, is no longer considered as the main trigger of fraud. Instead it is triggered by failures in the internalization of spiritual values into accountants. The author proceeded by stating that tawhid is a key to reduce fraud. Using this study on pragmatic accounting masculinity, we believe that accounting serves as the agent of capitalism proliferation. This is proven by the fifth article, which concluded that science can change the way people think. The research found changes in informants' mindset after attending courses on spirituality. In relation with accounting, the researcher revealed that accounting as science needs to be purified by moving the mindset toward a faith that God is the only truth. Still in critical atmosphere, the sixth article tried to formulate a new concept of accountability as a resistance to the conventional concept used in pragmatic accounting. The researcher then proposed prophetic accountability as a concept that considers accountability activities are parts of ibadah. This concept runs counter to pragmatic accounting's accountability, which sees stakeholders as the center of accountability. 


\section{Rahmanti \& Sawarjuno \\ Liberating Accounting with a Religio-Cultural Approach}

The standpoint that accounting is inseparable from tawhid is also proposed by the seventh article. The author expressed the fear of pragmatic accountants as a phobia to "other" forms of accounting, as in relating it with religious aspect. The research exemplified that pragmatic accounting is a secular science that opposes Islamic core teachings. One of the topics in accounting mostly criticized is profit-loss account. Many researchers believe that mistakes are present in accounting profit concepts. As in the eighth article, which used the thought of Ibnu Khaldun, a Muslim philosopher, the author defined earnings as incidentally gained profits so that profits are the compassion of Allah SWT. Opposing the definition, accounting sees earnings as a numerical concept in forms of subtraction of income by costs; all of which are purely present due to human activity. Once again, through the research pragmatic accounting claims itself a secular science.

Accounting studies also cover social activities such as CSR particularly in Islamic Financial Institutions (IFI). There are many researchers who start criticizing the pseudo meaning of CSR in Islamic financial sector. IFI tend to see that CSR invalidates their sharia-compliant status. The tendency comes from an assumption that stockholders are the main stakeholder. The ninth article countered it by concluding that the wellbeing of stakeholders (not stockholders) and customers are the focus of IFI's existence.

The tenth article criticizes the rigidness of pragmatic accounting. The author believes that the energy of love can scrape off the dogma and the rational, empirical, and objective traits of pragmatic accounting so that accountants enjoy love and blessing. In the research love refers to human's obedience to God. In other words, tawhid is believed can reduce pragmatic accounting's masculinity.

The analysis on the compiled articles provided us with information about religious values that are frequently related with critical studies on accounting; they are (1) tawhid, (2) justice, (3) brotherhood, (4) maslahah, (5) balance, (6) gratefulness, (7) sincerity, and (8) blessing. They appear to be the antithesis of masculinity. Table 3 concludes the paradox between the two value sources.

Table 4 The Paradox between Masculinity and Islamic Values

\begin{tabular}{cll}
\hline No. & \multicolumn{1}{c}{ Masculine } & \multicolumn{1}{c}{ Islamic Values } \\
\hline 1 & Secular & Tawhid; Gratefulness; Blessing \\
2 & Egoism & Justice \\
3 & Individualism & Brotherhood \\
4 & Greed & Maslahah \\
5 & Materialism & Balance \\
6 & Aggressiveness & Sincerity \\
\hline
\end{tabular}

The discovered Islamic values are relevant with Islamic theology proposed by Engineer (1999), who explained that tawhid is the believe of God's unity and the unity of mankind. No unity without brotherhood. Engineer (1997: 7) also asserted that 'adl (justice) and ahsan (virtue) are main concepts in the Quran. In support to the view, Nawab Haider Naqvi, a Pakistani economist also stated that the believe to God automatically calls for justice enforcement (Engineer, 1999:7). Balance and maslahah 


\section{Rahmanti \& Sawarjuno \\ Liberating Accounting with a Religio-Cultural Approach}

were also promoted by Engineer (1999:60) in the context of social balance, which can only be maintained if social wealth is equally used to provide for the society in a normal sense. Balance as a value is also mentioned in the Quran, surah al-Qashash verse 77:

"But seek, through that which Allah has given you, the home of the Hereafter; and [yet], do not forget your share of the world. And do good (to others) as Allah has done good to you. And desire not corruption in the land. Indeed, Allah does not like corrupters."

Referring to the verse, Islam requires that humans do not orient themselves only to material happiness which are frequently expressed as material ownership maximization. Through this verse Allah SWT reminds us the hereafter is the ultimate goal of life.

In addition to identifying religious values, the analysis on the articles is also useful to provide descriptions about how the values are used to criticize pragmatic accounting. The values are used as a tool to criticize pragmatic accounting from various accounting vantage points such as measurement concept, conceptual framework fraud, the role of science in changing mindset, criticism on accountability and profit, secularism of accounting, and the substantial of CSR activities. The analysis results strengthen this study in that (1) pragmatic accounting is really full of masculinity, so (2) accounting needs to be purified through (3) Islamic religious values. Therefore, the values are keys to liberate pragmatic accounting from masculinity.

\section{Revealing Awareness to Liberate Pragmatic Accounting}

This stage of analysis was conducted to understand how Islamic values successfully identified in the previous stage serve as a guideline for the informants in running their business. In conjunction with the results of the analysis in the previous stage, Islamic values implied from the interview are tawhid, justice, brotherhood, blessing, honesty, responsibility or amanah, gratefulness, and sincerity. This proves that data validity has been achieved through the application of triangulation between library research and interview.

Before proceeding with phenomenological analysis, there are reasons why we used accounting as the metaphor of business. Table 5 presents the reasons. The metaphorical process will prove how the internalization of Islamic values in informants can create a prospering business so that the process of liberating accounting form masculinity can be done by altering masculinity with Islamic values.

Table 5 Metaphors between Business and Accounting

\begin{tabular}{cll} 
No. & \multicolumn{1}{c}{ Business } & \multicolumn{1}{c}{ (Pragmatic) Accounting } \\
\hline 1 & $\begin{array}{l}\text { In general business is assimilated with } \\
\text { profit-seeking activities }\end{array}$ & Oriented to profit maximization \\
2 & Is a part of economic activities & Is a part of economic activities \\
3 & $\begin{array}{l}\text { Has both internal and external supporting } \\
\text { stakeholders }\end{array}$ & $\begin{array}{l}\text { Has both internal and external } \\
\text { supporting stakeholders }\end{array}$ \\
4 & Has many profit-maximizing strategies & Has many profit-maximizing policies \\
\hline
\end{tabular}




\section{Rahmanti \& Sawarjuno \\ Liberating Accounting with a Religio-Cultural Approach}

Business and accounting are similar in their objective. In general business activities are always related with profit attainment, similar to pragmatic accounting that aims at profit maximization to accommodate stockholders' interest. In business, there are many strategies to win the competition. The most popular one is Michael Porter's idea, which consist of cost leadership, differentiation, and focus. Similar to accounting, it has numerous policies for profit maximization, as in earnings management, which has various ways to "beautify" companies profit such as taking a bath, income minimization, income maximization, income smoothing, and timing revenue and expense recognition. Furthermore, both business and accounting are parts of economic activities related to the use of economic sources. Besides having internal stakeholders, i.e. employees and investors, business has external stakeholders, i.e. government, creditors, and customers. While accounting's internal stakeholders are employees and management, its external stakeholders are government, creditors, and stockholders. Those are the reasons that underpins the use of business as the metaphor of accounting.

Based on the transcendental phenomenology analysis consisting of noema, noesis, intentional analysis, dan eidetic reduction (refer to table 4), it is evident that business built upon Islamic values positively affect the social ecosystem. $R, S$, and $D$ who built their business on the foundation of tawhid and blessing do not make materialistic aspects as their main goals. In addition to having positive effect on employees' welfare, the spiritual values in fact enhances the performance of their business, as marked by the satisfaction of their customers. This finding confirms the statement of Choudhury (1989) that tawhid is able to bring social order to the society (Choudhury, 1989).

On the contrary, when a business is run by relying on masculinity, the business owner will certainly be obsessed to maximize profit, asset, and other materialistic wealth. Pragmatic accounting, which is currently believed as a truth, is really thick with masculinity. The transcendental phenomenology analysis on the interviews with the three informants has revealed that the internalization of Islamic values is able to replace the secularistic, egocentric, individualistic, greedy, materialistic, and aggressive masculinity. Therefore, one of the efforts of liberating pragmatic accounting is by internalizing Islamic values, i.e. tawhid, blessing, justice, brotherhood, maslahah, balance, and sincerity, in the entire parts of accounting as well as by reforming its conceptual framework.

For Engineer (1999), liberating Eastern civilization from westernization is a must. He refers to it as jihad against power arrogance, injustice, oppression on the weak, asset accumulation, and concentration of wealth. The Western culture hegemony does not only give birth to various pictures of injustice but also create class society. This contradicts the vision of Islam in brotherhood and equality (Engineer 1999:76). Westernization and developments oriented to a group of elites do not root from local society and culture which cause religio-cultural alienation. In addition to justice issues, Engineer (1999:11) also asserted that tawhid is the core of theology. As a liberator theology does not only speak about the unity of God but also mankind unity. 


\section{Rahmanti \& Sawarjuno \\ Liberating Accounting with a Religio-Cultural Approach}

Accounting as the product of Western civilization causes social disorders, so liberation becomes an urgency. The existing pragmatic accounting is in a status quo, which provides comfort for elites through maximization of profit, equity, and asset as reflected in financial reports. Similarly, Mulawarman (2014) stated that profit figure in profit-loss reports is the center of accounting interest for the satisfaction of owners, stockholders, and investors. Materialism is also reflected in the balance sheet politics (Mulawarman, 2014), in which "liabilities" post is effectively used by owners and management (internal stakeholders) to distribute "profit" to creditors (external stakeholders) to enjoy tax benefit from government. Involving creditors is also beneficial for the management since, as external parties, they do not have the right to control the company as investors do. The same also applies for "cash" post as an element of balance sheet and cash flow report. There are tradeoffs between management and owners, stockholders, or investors. Mulawarman (2014) further explained that, in management's interest, cash ownership means control and intervention over the company's operation. For external parties, cash ownership by the company indicates the potential of earnings distribution for itself in form of dividend. Another indicator of masculinity is also reflected in equity in that, according to Mulawarman (2014) the values reflected in equity are used more for the wellbeing of owners and investors (shareholders), not the stakeholders. This condition, according to Engineer (1999), is the refection of wealth concentration on elite groups.

Islam forbids such behavior as mentioned in the Quran verse number 59 verse 7 that "... it will not be a perpetual distribution among the rich from among you". A society in which some of its members exploit other members who are weak and oppressed cannot be called as Islamic society. The secularity in pragmatic accounting only features rational strength, so materialism is regarded as the best parameter for success and happiness. The material success leads to material sufficiency for capital holders. This is the reflection of egoistic and individualistic masculinity, while greed and aggressiveness are reflected in the politics of financial reports as explained above. Aggressiveness toward wealth is highly palpable in one of accounting policies, the earnings management. This "earnings manipulation" technique in fact makes earnings a "simulacrum" ${ }^{1}$ that obfuscates the real value of earnings using images.

The liberation of pragmatic accounting from masculinity can be done by internalizing Islamic values into the corpus of accounting, as indicated by the success of the informants in creating prospering business (as the metaphor of accounting). the conceptual framework of accounting as the foundation of pragmatic accounting is the first basic thing that must be reformed considering that the conceptual structure formulates the objective of financial reporting, its qualitative characteristics, elements, assumptions, principles, and hindrances. At the first level, the objective of financial reporting is to provide information about the activities of an entity that is useful for the decisions of investors, debtors, and creditors (Kieso et al, 2011). The tycoons are referred by Engineer (1999) as elite groups where wealth is concentrated. Masculinity is

\footnotetext{
${ }^{1}$ The term "simulacrum" was used by Jean Baudrillard to refer images that replace true reality; the image is even separated or detached from the reality (Kamayanti, 2016:156).
} 


\author{
Rahmanti \& Sawarjuno \\ Liberating Accounting with a Religio-Cultural Approach
}

very sensible in the financial reporting's statement of objective. Hence, liberation must be carried out by internalizing Islamic values of tawhid, justice, brotherhood, and maslahah so that accounting benefits wider societies, not only the industrialists. Value reformation must also be done in elements other than conceptual framework, e.g. assumption. One of the assumptions in pragmatic accounting report is monetary unit since financial reporting only covers information measurable in the unit. Islam teaches that wealth is not the real source of happiness but teaches balance between life and hereafter happiness. Therefore, monetary unit assumption must be replaced with Islamic value assumption such as material and immaterial balance as well as blessing. The internalization of Islamic values in pragmatic accounting is expected to produce a new accounting that is more altruistic for the attainment of maslahah.

\title{
Conclusion
}

Pragmatic accounting is believed to be built on masculinity-filled capitalism. As a foreign product of Western culture, accounting tends to be egoistic, rational, materialistic, and objective. These traits eventually lead to religio-cultural alienation in forms of injustice, oppression, and class society. Even though accounting has claimed itself a reporting tool that supports stakeholders' decision making, its financial reporting has deviated from its objective by prioritizing the interest of capital holders, i.e. stockholders and lenders. In its essence, accounting is not a value-free "tool". Accounting as the product of culture has the power of supporting certain concepts. In the context of pragmatic accounting, it supports the development of capitalism as an agent. This makes the reconstruction of pragmatic accounting an urgency.

Masculinity runs counter to altruistic, intuitive, subjective, and spiritualistic Islamic values. This opposition is caused by differences in value evolution hierarchy between the West and Islam. As masculinity is derived from people's or local traditions, Islamic values were born from thoughts guided by Allah SWT, the divine guidance. Thus, Islamic values must not only be the guideline for human behaviors but also be the epicenter of all science.

Through the application of historical studies on several empirical researches published in JAMAL, we found that Islamic values used in critical studies on accounting are tawhid, justice, brotherhood, maslahah, balance, and sincerity; all of which oppose masculinity. The values were used by some empirical studies to criticize the masculinity of pragmatic accounting in, for example, measurement concept conceptual framework, fraud, the role of science in shaping mindset, criticism on accountability and profit concepts, secularism of accounting, and criticism on the substances of CSR activities. The findings support this research in that pragmatic accounting is indeed full of masculinity, so it needs to be purified using Islamic religious values.

To understand how the Islamic values can become the liberator for pragmatic accounting from its masculinity, this research uses business activity as its metaphor since both have similarities in multiple aspects. Phenomenology was then applied to 
reveal informants' awareness concerning the internalization of Islamic values in the management of their business. Through an analysis consisting of noema, epoch, noesis, intentional analysis, and eidetic reduction, we conclude that the internalization of Islamic values has led the informants toward better business management, which is not oriented only on profit but also on social welfare. Referring to the fact, the masculinity of pragmatic accounting must be replaced with Islamic values so that it can release itself from the trap pf materialism. The process must not stop here. In order to ensure that Islamic values are truly inherent in the spirit of accounting, the conceptual framework, which serves as the foundation of pragmatic accounting, must be purified by internalizing Islamic values. This is what is called as value internalization. When accounting has been released from masculinity, so the term pragmatic must be dropped, its entire activities will reflect the virtues of Islamic values and help the establishment of social ecosystem welfare.

\section{References}

Abdurahim, A. (2013). Oksidentalisme dalam perbankan syariah. Jurnal Akuntansi Multiparadigma, 4(1), 14-25. http://dx.doi.org/10.18202/jamal.2013.04.7179

Ahmad, A. (2020). The Role of Values in Development of Thought, Culture, and Civilization. IIIT Online Class. Retrieved from: https://www.youtube.com/watch?v $=35 \mathrm{G} 8 \mathrm{pYhhpfw}$

Ahmed, H. I., \& Barikzai, S. A. K. (2016). Objectives of Islamic Finance achieved by Islamic Banks. Al-Adwa, 45 (31), 45-65. Retrieved from http://journals.pu.edu.pk/pu/images/journal/szic/PDF/English/4$\% 20$ Iftakhar $\% 20$ Ahmad $\% 20$ Artical.pdf

Asutay, M. (2007). Conceptualisation of the second best solution in overcoming the social failure of Islamic banking and finance: examining the overpowering of homoislamicus by homoeconomicus. Journal of Economics and Management, 15(2), 167-195. Retrieved from https://journals.iium.edu.my/enmjournal/index.php/enmj/article/view/134

Bozeman, A.B. (1975). Civilizations under Stress: Reflections on Cultural Borrowing and Survival. The Virginia Quarterly Review, 50(1), 1-18. https://doi.org/10.2307/2643558

Bryer, R.A. (2000). The History of Accounting and the Transition to Capitalism in England. Part One: Theory. Accounting, Organizations and Society, 25(2), 131-162. Retrieved from https://econpapers.repec.org/article/eeeaosoci/v_3a25_3ay 3a2000 3ai 3a2 3ap_3a 131-162.htm

Burrell, G., \& Morgan, G. (1979). Sociological Paradigms and Organisational Analysis: Elements of the Sociology of Corporate Life. Great Britain: Arena.

Capra, F. (2000). The Tao of Physics. Terjemahan. Yogyakarta: Jalasutra.

Carrier, JG (ed). (2005). A Handbook of Economics Anthropology. USA: Edward Elgar.

Chiapello, E. (2007). Accounting and the birth of the notion of capitalism. Critical Perspectives on Accounting, 18(3), 263-296. https://doi.org/10.1016/j.cpa.2005.11.012

Choudhury, M. A. (1989). The Blending of Religious and Social Orders in Islam. International Journal of Social Economics, 16(2), 13-45. https://doi.org/10.1108/03068298910133043

Davie, S. S. (2010). Accounting, Female \& Male Gendering, And Cultural Imperialism. Accounting, Auditing \& Accountability Journal, 30(2), 247-269. Retrieved from https://ideas.repec.org/a/eme/aaajpp/aaaj-08-2012-01080.html 
Dusuki, A. W. (2008). What does Islam Say CSR?. Review of Islamic Economics, 12(1), 5-28. Retrieved from http://www.iefpedia.com/english/wpcontent/uploads/2009/09/What-Does-Islam-Say-About-Corporate-SocialResponsibility-CSR.pdf

Eliot. (1948). Banquet speech. NobelPrize.org. Nobel Media AB 2020. Retrieved from https://www.nobelprize.org/prizes/literature/1948/eliot/speech/

Engineer, A.A. (1999). Islam dan Teologi Pembebasan. Yogyakarta: Pusataka Pelajar Offset.

Farhan, A. (2016). Hermeneutika Romantik Schleiermacher Mengenai Laba dalam Muqaddimah Ibnu Khaldun. Jumal Akuntansi Multiparadigma, 7(1), 61-29. http://dx.doi.org/10.18202/jamal.2016.04.7005

Farjaudon, A. (2013). In search of consensus : The role of accounting in the definition and reproduction of dominant interests. Critical Perspectives on Accounting, 24(2), 154-171. https://doi.org/10.1016/j.cpa.2012.09.010

Fauzia, I. Y. (2018). Perilaku Pebisnis dan Wirausaha Muslim dalam Menjalankan Asas Transaksi Syariah. Jurnal Akuntansi Multiparadigma, 9(1), 38-56. https://doi.org/10.18202/jamal.2018.04.9003

Funnell, W., \& Robertson, J. (2011). Capitalist accounting in sixteenth century Holland: Hanseatic influences and the Sombart thesis. Accounting, Auditing \& Accountability Journal, 24(5), 560-586. https://doi.org/10.1108/09513571111139102

Gallhofer, S. (1998). The silences of mainstream feminist accounting research. Critical Perspectives on Accounting, 9(3), 355-375. https://doi.org/10.1006/cpac.1997.0191

Hammond, T. (2003). History from accounting's margins: international research on race and gender. Accounting History, 8(2), 9-24. https://doi.org/10.1177\%2F103237320300800102

Haniffa, R. \& Hudaib, M. (2007). Exploring the ethical identity of Islamic banks via communication in annual reports. Journal of Business Ethics, 76, 97-116. Retrieved from https://link.springer.com/article/10.1007/s10551-006-9272-5

Hasegawa, M. (2011). The Uniqueness of Humans and an Anthropological. Japanese Association of Medical Sciences (JAMS), 139(4), 886-890. Retrieved from https://www.med.or.jp/english/journal/pdf/2011_04/229 233.pdf

Hassan, M.K. \& Alamgir, D.A.H. (2002). Microfinancial services and poverty alleviation in Bangladesh: a comparative analysis of secular and Islamic NGOs", in Iqbal, M. (Ed.), Islamic Economic Institutions and the Elimination of Poverty. Leicester: The Islamic Foundation

Haynes, K. (2017). Accounting as gendering and gendered: A review of 25 years of critical accounting research on gender. Critical Perspectives on Accounting, 43(1), 110-124. https://doi.org/10.1016/j.cpa.2016.06.004

Heidhues, E., \& Patel, C. (2012). A critique of Gray's framework on accounting values using Germany as a case study. Studies in Managerial and Financial Accounting, 23(2012), 17-42. https://doi.org/10.1108/S1479-3512(2012)0000023007

Indriasari, R. (2015). Ketika Sains [Akuntansi] Bertasbih Spirit Cinta. Jurnal Akuntansi Multiparadigma, 6(2), 316-326. https://doi.org/10.18202/jamal.2015.08.6025

Jurana, J., \& Khairin, F. N. (2017). Pembebasan Mind Set Akuntan melalui Pembelajaran Filsafat Ilmu dan Spiritual. Jurnal Akuntansi Multiparadigma, 8(1)107-125. https://doi.org/10.18202/jamal.2017.04.7043

Kamayanti, A. (2013). Riset Akuntansi Kritis: Pendekatan (Non) Feminisme Tjoet Njak Dhien. Jurnal Akuntansi Multiparadigma, 4(3), 361-375.

https://doi.org/10.18202/jamal.2013.12.7203

Kamayanti, A. (2016). Fobi ( A ) Kuntansi : Puisisasi dan Refleksi Hakikat. Jurnal Akuntansi Multiparadigma, 7(1), 1-16. http://dx.doi.org/10.18202/jamal.2016.04.7001 
Kamla, R. (2009). Critical Insights into Contemporary Islamic Accounting. Critical Perspectives on Accounting, 20(8), 921-932. https://doi.org/10.1016/j.cpa.2009.01.002

Kieso, D.E., Jerry, J.W., \& Terry, D.W. (2011). Intermediate Accounting, IFRS Edition. Haboken, NJ: John Willey \& Sons Inc.

Kohzadi, H., \& Azizmohammadi, F. (2011). T . S . Eliot's Interpretation of Culture. Journal of Basic and Applied Scientific Research, 1(12), 2823-2825. Retrieved from https://www.textroad.com/pdf/JBASR/J.\%20Basic.\%20Appl.\%20Sci.\%20Res.,\%20 1(12)2823-2825,\%202011.pdf

Kusdewanti, A. I., \& Hatimah, H. (2016). Membangun Akuntabilitas Profetik. Jumal Akuntansi Multiparadigma, 7(1)223-239. https://doi.org/10.18202/jamal.2016.08.7018

Maali, B. \& Napier, C. (2010). Accounting, religion and organisational culture: the creation of Jordan Islamic Bank. Journal of Islamic Accounting and Business Research, 1(2), 92-113.

Retrieved from

https://www.emerald.com/insight/content/doi/10.1108/17590811011086705/full/p df

Muchlis, S., \& Sukirman, A. S. (2016). Implementasi Maqashid Syariah dalam Corporate Social Responsibility di PT Bank Muamalat Indonesia. Jumal Akuntansi Multiparadigma, 7(1), 120-130. https://doi.org/10.18202/jamal.2016.04.7011

Mulawarman, A. D., \& Kamayanti, A. (2018). Towards Islamic Accounting Anthropology: How secular anthropology reshaped accounting in Indonesia. Journal of Islamic Accounting and Business Research, 9(4), 629-647. https://doi.org/10.1108/JIABR-022015-0004

Mulawarman, A.D. (2014). On Holistic Wisdom Core Datum Accounting: SHifting from Accounting Income to Value Added Accounting. The International Journal of Accounting and Business Society, 22(1), 69-92.

Nichols, D., Robinson, R. K., Reithel, B. J., \& Franklin, G. M. (1997). An exploratory study of sexual behavior in accounting firms: Do male and female CPAs interpret sexual harassment differently?. Critical Perspectives on Accounting, 8(3), 249-264. https://doi.org/10.1006/cpac.1996.0109

Nurindrasari, D., Triyuwono, I., \& Mulawarman, A. D. (2018). Konsep Pengukuran Kinerja Berbasis Kesejahteraan Islam. Jurnal Akuntansi Multiparadigma, 9(3), 394-416. https://doi.org/10.18202/jamal.2018.04.9024

Plog, F., \& Bates, D.G. (1976). Cultural Anthropology. Knopf: University of California.

Rahmanti, V. N., Kamayanti, A., \& Mulawarman, A. D. (2013). Menggeser paradigma Stock Concept Menuju Flow Concept: Kritik atas Net Revenue Sharing pada Akuntansi Mudharabah. Silatnas FORDEBI UNS Surakarta, (Rad 2006), 1-24. Retrieved from http://ajidedim.lecture.ub.ac.id/files/2014/01/2013 Rahmanti-Mulawarman$\underline{\text { Kamayanti.pdf }}$

Sarker, M.A. (1999). Islamic Business Contracts, Agency Problem and the Theory of the Islamic Firm. International Journal of Islamic Financial Services, 1(2), 1-15. Retrieved from http://iaif.ir/images/khareji/articles/other/46.pdf

Sawarjuwono, T. (2002). Accounting is Magic. Edisi Perdana. Jakarta: Salemba Empat.

Soediro, A., \& Meutia, I. (2018). Maqasid Syariah as a Performance Framework for Islamic Financial Institutions. Jurnal Akuntansi Multiparadigma, 9(1), 70-86. https://doi.org/10.18202/jamal.2018.04.9005

Špiláčková, M. (2012). Historical Research in Social Work - Theory and Practice. ERIS Web Journal, 3(2), 22-33. Retrieved from http://periodika.osu.cz/eris/dok/201202/04 historical research in social work.pdf

Tong, D. (1991). Development and Reform of China's Education. International Journal of Social Economics, 1810(4), 132-136. https://doi.org/10.1108/03068299110143436 
Urumsah, D., Wicaksono, A. P., \& Hardinto, W. (2018). Pentingkah Nilai Religiusitas dan Budaya Organisasi untuk Mengurangi Kecurangan? Jurnal Akuntansi Multiparadigma, 9(1), 156-172. https://doi.org/10.18202/jamal.2018.04.9010

Yamey, B.S. (1949). Scientific Bookkeeping and the Rise of Capitalism. The Economic History Review, 1(2\&3), 99-113. https://doi.org/10.1111/j.1468-0289.1949.tb00108.x 